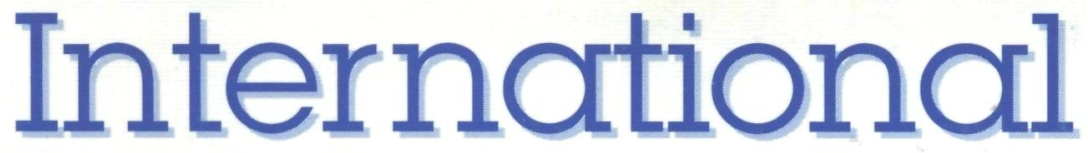

Labor and
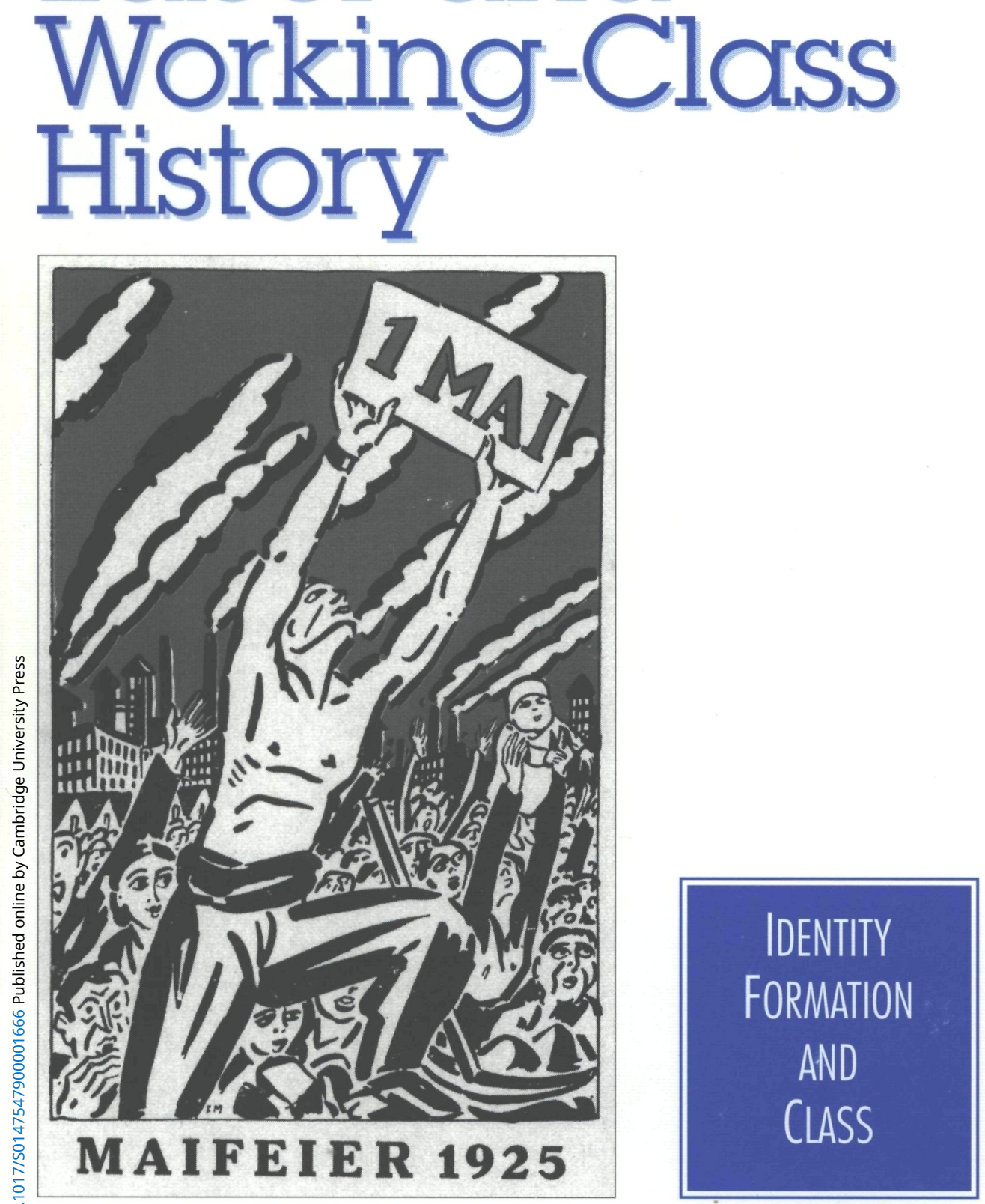


\section{INTERNATIONAL LABOR AND WORKING-CLASS HISTORY}

\section{EDITORS}

\author{
Helmut Gruber \\ Polytechnic University \\ Louise A. Tilly \\ New School for \\ Social Research
}

\section{ASSISTANT EDITOR}

Guy Baldwin

New School for

Social Research

\section{REPORTS EDITOR}

\section{Bruce Levine \\ University of Cincinnati}

\section{ISSUE COORDINATOR}

Michael Hanagan

\section{EDITORIAL BOARD}

\author{
Dorothy Sue Cobble \\ Rutgers University \\ Lizabeth Cohen \\ New York University \\ Geoff Field \\ State University of \\ New York, Purchase \\ Michael Hanagan
New School for
Social Research \\ Ira Katznelson \\ Columbia University \\ Stephen Kotkin \\ Princeton University
}

Bruce Levine

University of Cincinnati
David Montgomery Yale University

Mary Nolan

New York University

Anson Rabinbach

The Cooper Union

Philip Scranton

Hagley Museum

and Library

Judith Stein

City College

of New York

Barbara Weinstein

SUNY, Stony Brook

International Labor and Working-Class History (ISSN 0147-5479) is published twice yearly, in the spring and the fall, by Cambridge University Press for the editors of $I L W C H$. Additional support is provided by the New School for Social Research. Annual subscription rates for Numbers 49 and 50. 1996: Institutional US $\$ 40.00$ in the USA, Canada, and Mexico, UK $£ 30.00$ in the rest of the world; Individual US $\$ 20.00$ in the USA. Canada, and Mexico. UK $\$ 15.00$ in the rest of the world; Single parts US $\$ 22.00$ in the USA, Canada, and Mexico, UK $\$ 16.00$ in the rest of the world. Prices include surface postage and insurance. Add UK $\$ 8.00$ for airmail.

Editorial Office: Manuscripts, editorial correspondence, and books for review should be addressed to Editor, $I L W C H$, Center for Studies of Social Change, New School for Social Research. 80 Fifth Avenue, New York, NY 10011. Tel. (212) 229-5921; Fax (212) 229-5929; INTERNET: ILWCH $a$ CSSC.NEWSCHOOL.EDU.

Publishing, Subscription, and Advertising Offices: Cambridge University Press, 40 West 20th Street, New York, NY 10011-4211; or Cambridge University Press, The Edinburgh Building. Shaftesbury Road, Cambridge CB2 2RU, England.

Copyright 1996 International Labor and Working-Class History. Inc. All rights reserved. No part of this publication may be reproduced. in any form or by any means. electronic. photocopying or otherwise, without permission in writing from Cambridge University Press. Photocopying information for users in the USA: The Item-Fee Code for this publication (ISSN $0147-5479 / 96 \$ 7.50+.10$ ) indicates that copying for internal or personal use beyond that permitted by Sec. 107 or 108 of the US Copyright Law is authorized for duly registered with the Copyright Clearance Center (CCC) Transaction Reporting Service. provided that the appropriate remittance of $\$ 7.50$ per article is paid directly to: CCC. 222 Rosewood Drive. Danvers. MA 01923. Specific written permission must be obtained for all other copying.

The Board of Consulting Editors may be found immediately following the contents. See the back of the journal for information concerning submissions to the journal.

Cover photo: Frans Masereel, Maifeier in Leipzig 1925. Copyright (C) Frans Masereel Stiftung Saarbrucken, Germany. 


\title{
IDENTITY FORMATION AND CLASS
}

"The Labour of the Country Is the Wealth of the Country":

Class Identity, Consciousness, and the Role of Discourse

in the Making of the English Working Class

Marc W. Steinberg

The Domestic Image and Factory Culture: The Cotton District in Mid-Nineteenth-Century England

Carol E. Morgan

"The Man Transformed into a Maiden"? Languages of Grievance and the Politics of Class in Germany, 1850-1914

Kathleen Canning

The Mysterious Case of the Missing Men: Gender and Class in Early Industrial Medellín

Ann Farnsworth-Alvear

Working for Democracy: Brazil's Organized Working Class in Comparative Perspective

Anthony W. Pereira

A Case of Mistaken Identity: The Irish in Postwar Britain

Kathleen Paul

\author{
ARTICLE \\ Organized Labor, National Politics, and Second-Wave Feminism \\ in the United States, 1965-1975 \\ Dennis A. Deslippe
}

\section{COUNTRY REPORT}

Labor History in New Zealand

John E. Martin 


\section{REPORTS AND CORRESPONDENCE}

International Colloquium on Workers and the Intelligentsia in Russia in the Late Nineteenth and Early Twentieth Centuries

William G. Rosenberg, Mark D. Steinberg, and Reginald E. Zelnik

Society for French Historical Studies

Judith A. Degroat

Organization of American Historians

Jennifer Klein, David Brundage, and Cecilia Elizabeth O'Leary

Workers and the Environment: Pacific Northwest Labor History Association Nils Sonntag

\section{BOOK REVIEWS}

Capitalism, Socialism, Ecology, by André Gorz

Reviewed by Siegfried Mattl

The Labour Aristocracy, 1851-1914, by Trevor Lummis

Reviewed by Eric Hopkins

Labour Women: Women in British Working Class Politics, 1918-1939, by Pamela M. Graves

Reviewed by Anna Clark

Politics and the People: A Study in English Political Culture, c. 1815-1867, by James Vernon

Reviewed by Eugenio Biagini

The Foreign Worker and the German Labor Movement: Xenophobia and Solidarity in the Coal Fields of the Ruhr, 1871-1914,

by John J. Kulczycki

Reviewed by Craig Patton

The Weaver's Knot: The Contradictions of Class Struggle and Family Solidarity in Western France, 1750-1914, by Tessie P. Liu

Reviewed by Lizabeth Zack

Citizen Worker: The Experience of Workers in the United States

with Democracy and the Free Market during the Nineteenth Century,

by David Montgomery

Reviewed by Jeanne Boydston

A Very Social Time: Crafting Community in Antebellum New England, by Karen V. Hansen

Reviewed by David Jaffee

Forging American Communism: The Life of William Z. Foster,

by Edward P. Johanningsmeier

Reviewed by James Barrett 
Becoming Mexican American: Ethnicity, Culture and Identity in Chicano Los Angeles, 1900-1945, by George J. Sánchez

Reviewed by Zaragosa Vargas

Indentured Labor, Caribbean Sugar: Chinese and Indian Migrants to the British West Indies, 1838-1918, by Walton Look Lai

Reviewed by $O$. Nigel Bolland

Peasant Metropolis: Social Identities in Moscow, 1929-1941, by David L. Hoffman

Reviewed by Kenneth Straus 


\section{BOARD OF CONSULTING EDITORS}

Kathryn Amdur

Emory University

Gerd Callesen

Arbejderbevaegelsens Bibliotek

og Arkiv, Copenhagen

Frederick Cooper

University of Michigan

Patrizia Dogliani

University of Bologna

Geoff Eley

University of Michigan

Elizabeth Faue

Wayne State University

Patrick Fridenson

Ecole des Hautes Etudes

en Sciences Sociales

Andrew Gordon

Harvard University

Pat Hudson

University of Liverpool

Linda Kerber

University of Iowa

Alex Keyssar

Duke University

Nelson Lichtenstein

University of Virginia
Louis Menashe

Polytechnic University

Ruth Milkman

University of California, Los Angeles

Lutz Niethammer

Kulturwissenschaftliches Institut, Essen

Pamela Radcliff

University of California, San Diego

Dilip Simeon

International Institute for Asian

Studies, Leiden

Ronald G. Suny

University of Michigan

Marcel van der Linden

International Review of Social History, Amsterdam

Adelheid von Saldern

Universität Hannover

Sean Wilentz

Princeton University

J. M. Winter

Pembroke College, Cambridge

University

Sergei Zhuravlev

Institut Rossiiskoi Istorii, Moscow 